\title{
Responding to Contemporary Issues: From a Sharia Arbitration Perspective
}

\section{Adnan Tawfiq Wrikat, Anas Mohd. Yunus, Najihah Abd Wahid}

To Link this Article: http://dx.doi.org/10.6007/IJARBSS/v10-i11/8149

DOI:10.6007/IJARBSS/v10-i11/8149

Received: 27 September 2020, Revised: 25 October 2020, Accepted: 15 November 2020

Published Online: 27 November 2020

In-Text Citation: (Wrikat, Mohd. Yunus, \& Abd Wahid, 2020)

To Cite this Article: Wrikat, A. T., Mohd. Yunus, A., \& Abd Wahid, N. (2020). Responding to Contemporary Issues: From a Sharia Arbitration Perspective. International Journal of Academic Research in Business and Social Sciences. 10(11), 879-885.

Copyright: @ 2020 The Author(s)

Published by Human Resource Management Academic Research Society (www.hrmars.com)

This article is published under the Creative Commons Attribution (CC BY 4.0) license. Anyone may reproduce, distribute, translate and create derivative works of this article (for both commercial and non-commercial purposes), subject to full attribution to the original publication and authors. The full terms of this license may be seen at: http://creativecommons.org/licences/by/4.0/legalcode

\section{Vol. 10, No. 11, 2020, Pg. 879 - 885}

Full Terms \& Conditions of access and use can be found at http://hrmars.com/index.php/pages/detail/publication-ethics 


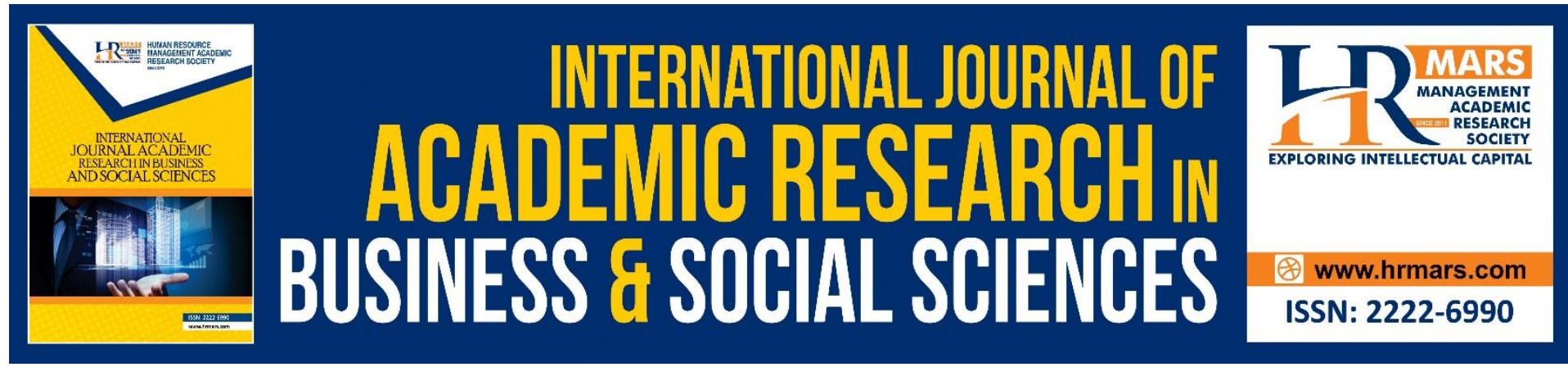

\title{
Responding to Contemporary Issues: From a Sharia Arbitration Perspective
}

\author{
Adnan Tawfiq Wrikat, Dr. Anas Mohd. Yunus, Dr. Najihah Abd \\ Wahid
}

Sultan Zine El Abidine University

Email: mesterjordan78@gmail.com

\begin{abstract}
In this study we will look at Islamic law in terms of its ability to address contemporary issues such as terrorism. Organizations terrorists that make Islam a cover for their aims are exploiting the meaning of Sharia arbitration to spread among Islamic societies, claiming that only they have the right path that protects the interests of societies. The point which help those organizations that the Islamic countries talk with their people that the source of their constitutions is Islam, and in same time their people become know the different between Islam law and the made- man laws. Frome here our study comes to answer of those questions which emerging from Muslim societies about the ability of Islamic law to be the legal and constitutional basis for organizing community relation. This research, will answer a question about the ability of Sharia law to be a legislative and legal source in Islamic countries. The importance of this paper is to identify the possibility of considering Sharia as a law regulating relations, and to identify the truth about the relationship between Islam and terrorism represented by organizations seeking to use religion as a means for them to obtain certain benefits. Study methodology, the comparative, descriptive, and analytical approach to achieve realistic results.
\end{abstract}

Keywords: Arbitration, Sharia.

\section{Introduction}

Resorting to Sharia law as a rule in human relations is a real challenge facing Muslims in general, not because of its impotence, but has proven its organizational ability over time, and not because of Western rejection, for the West in the end is a different nation with its culture, but because of the presence of a large number of Islamic community who reject this idea in all Its details (Ansary, 2008). The issue of codifying Sharia law, or in particular legalizing transactions in Islamic law, is not the result of this age, but there are many discussions that took place around it. The codification of Sharia is the drafting of the provisions of transactions and other contracts in the form of legal articles that are easy to refer to (Al Zuhaili, 2014). Sharia arbitration means making Islamic law the actual content of the constitution and law (Ahmad, 2001). The Arab Spring revolutions opened up the issue of binary Islam as the religion of a ruling regime in Islam, especially after the arrival of Islamic currents to the presidency in the elections. At the same time, terrorist organizations find that this issue is the main focus 
upon which these organizations base their ideas and demands. Terrorist organizations aim to establish an Islamic caliphate (Colin, 2019). The Islamic religion, in its truth, fights terrorism, and considers anything against people's rights a crime. Therefore, it is surprising that we find terrorists demanding that Islamic law be made the source of relationships between people, although they consider terrorism a strategic thinking to achieve their aims.

\section{The Religious Perspective of Sharia Arbitration}

Ibn Baz fatwa in this regard :The obligatory of arbitration by the law of God. That is why it is forbidden for a Muslim to arbitrate without the law of God. The scholars interpreted worship as all that God loves and is pleased with, both outward and inward words and deeds (Ansary,2008). This indicates that worship requires: complete submission to God Almighty, and for a person's life to be based on the law of God, and therefore submit in all his behavior and actions to the law of God. The imperative of faith is the knowledge that the judgment of God is the best of rulings and the most complete, and that the duty is to obey Him, with satisfaction and submission. It is not permissible for a Muslim to refer to man-made courts except when necessary if there are no Sharia courts. In the event of disagreement and conflict, whether it is between one state and another, or between groups, or between one Muslim and another, then the judgment belongs to God. There is a consensus among Muslims that the Khilafah is a legitimate duty, and only the Kharijites reject this idea, who do not believe in any kind of system of government as it is unnecessary according to their view as people can organize their affairs without a ruling over them (Hassan, Azmi \& Abubakar, 2017).

\section{Sharia Response to Various Crimes}

Islamic law dealt with various crimes that target individuals, with the aim of protecting a person over his soul, money and honor. And it has included the corresponding penalties for various crimes. Even new crimes, especially at the international level, have been strictly criminalized by Sharia law, and among these crimes is terrorism.

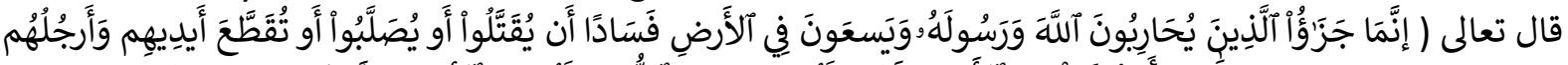

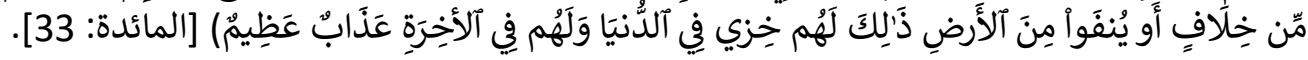

In this verse we find the word (يحاريون), which according to the Arabic dictionary means exaggeration in war: Which is derived from the word war and fight. According to (Ryan, 2018), Fighting means cutting off the road for a person or group and making the road surrounded by fear, an image of corruption that is realized on the ground. The warriors here in this verse are the group that is exposed with weapons to other people with the intention of killing, stealing or terrorizing (Al Bishri, 2012). If we go to make a comparison between contemporary acts and images of terrorist crimes with what Muslim jurists have proven of the meaning of this verse, we find that they are united and agreed in terms of the psychological element and spreading terror or fear, with the intention of terrorism, which makes us notice their agreement with the operations that come with the description of terrorism in our contemporary era, especially what we witness of acts described as maritime piracy and the hijacking of aircraft. We conclude by saying that this verse in Islamic law is the semantic meaning and the realistic picture of the crime of terrorism according to humanitarian or positive laws. If we go to the term legitimate defense in law and from the political point of view, we will find that Sharia has dealt with this issue. Islam has shown cases of the use of force. The same applies to international relations, as Islam has indicated that it is based on peace and respect for agreements, and the prohibition and prevention of aggression against others without a legitimate authorization (Piazza, 2009). 


\section{Sharia arbitration in legal human relations}

Islamic law, including its provisions and rules, is valid for every time and place, capable of being the actual and true basis and source for organizing the individual's relations with other individuals, the relationship of the individual with the state, and the relations of countries with each other, and with its organizational contents it facilitates life in various life affairs. All this gives it the ability to be the law governing people's conditions. The reason for the failure of Sharia to appear as a law that regulates various matters is due to the failure to codify its provisions and rules in laws similar to those in man-made laws (Abdul Hadi, 2014). In this context, we find that an attempt was made in Egypt to codify the Sharia, through the Egyptian People's Assembly from 1978 to 1983, in its session, July 1, 1982, the Council succeeded in approving five laws related to civil transactions, maritime trade, litigation procedures, Trade law, and the penal code (Al Bishri, 2012). Despite the fact that these laws have not been implemented, we can consider them as a reference within the framework of organizing human relations in line with man-made laws. The motive for codifying the provisions of Islamic law is many things, foremost of which comes the blocking of its exclusion from application under the pretext of its lack of clarity or lack of specification in an article that is easy to refer to (Al Faidi, 2015). Moreover, codifying Islamic law is a matter required by some Islamic countries constitutions which stipulate that the principles and provisions of Islamic law are the main source of legislation, and according to the constitutional text, the legislation issued by the legislative authority does not contradict Islamic law, which may lead to its abolition due to its violation of the constitution (Hassan, Azmi \& Abubakar, 2017).

$$
\text { قال تعالى (فَاتَّقُوا اللَّة مَا اسْتَطَعْتُمْ) [التغابن:16]. }
$$

(Ahmad, 2001) says, regarding the issue of arbitration, that this verse is suitable for being a title to be included in the use and activation of Sharia, as the ruler cannot eliminate the deviations that exist in society all at once, rather he needs time to do so.

\section{Sharia as a system of government}

Many people see that the Sharia, although it is suitable for application in the relations of society, but it is not suitable for application as a general system of the state. Islamic thinker Nasser Hamid Abu Zaid wrote: Separating religion from the state other than separating religion from society, no one can separate religion from society (Hassan, 2006). Religions are a social component, not just an individual idea. Some Muslim intellectuals admit the mistake they believed in, which is that Islam knows, like Christianity, the religious state, and that when religion becomes a government, this government becomes a burden on everyone (Hasan, 2007). Many believe that such regimes are no longer acceptable in our contemporary era, and that they have ended historically, and the adoption of such a system leads to chaos. Those who hold this position adopt the prevailing opinion in the midst of societies that politics is one thing, and Islam is another. Some seek to prove that the idea of a "caliphate" is not a fundamental element of Islam, and that Islam has not imposed a specific type of authority. Some believe that Islam is based on a humanitarian mission that does not include the establishment of a state, but rather aims to achieve brotherhood among the people, and therefore Islam is based on achieving an authority based on conscience, not the state. The constitution of Islam in its law is based on morals, so it can be the rule of life. Where the owners of this opinion say that the Prophet of God, peace and blessings be upon him, created a nation and not a state, and those with this view reject the idea of the state on the grounds that it carries the meaning of power, and all of these are for God alone. The absence of anything in the Holy Qur'an indicates the form of the system of government, just as the idea 
of governance was not clear in the rules during the era of the Prophet (may God's prayers and peace be upon him) in Medina, and that the Prophet did not change the ruling systems that prevailed in the Badia societies, but focused only on to adopt justice and freedom in judgment (Hamele, Poss \& Sweney, 2014). Islam came to be a comprehensive idea of change, and it has the ability to establish a state, and the indication of this is its ability to unite the Arabs under the banner of one state, although it is the first time that they know the form of the state (Rana, 2008). Islam is a "religion and state", the model for that state, which is the period of the rule of Omar bin Abdulaziz, which shows the spirit of the Muslim state and its ideal form for its era. For some, the "caliphate" is "the system of government in Islam." Despite the recognition of those who advocate the caliphate that it does not include all the rules of constitutional law according to modern legislation. Therefore, they seek to modernize the "caliphate" pattern in a way that is based on the principle of separation of powers, and they see that the divine will is expressed by the nation, not the caliph. They believe that the caliphate must be based on integration between religious and worldly affairs, and that it is any caliphate that requires the unity of the Islamic world. Supporters of the caliphate respond to those who say that it was established through force, that there was confusion between the method of choosing the ruler and the form of government. They also see that Islam is not only a religious system, but also a state that the Prophet (may God bless him and grant him peace) established and exercised the duties of the ruler. There are many attempts in Islamic countries to adopt Islamic legislation. In Pakistan on May 17, 1991 Parliament approved a bill making Islamic Sharia the supreme law in the country, and in Yemen on May 15, 1991, the people chose an Islamic constitution, and on January 1, 1991 in Sudan a decree was issued by the President of the Republic calling for the application of Islamic law in the country (Schouten, 2010). The Madinah Paper is a document written by the Prophet, may God's prayers and peace be upon him, among the residents of Medina, which includes their rights and duties. This document was considered as the constitution that governs the first Islamic state (Ramarkrishna, 2016).

\section{Conclusion}

The political formation of the Nation of Islam is one that takes place in the Shura Council, and without it, the Nation of Islam does not follow its right path. Islamic political thought was confined to the issue of "the caliphate" in terms of its conditions and specifications. In essence, it is merely an organizational picture of how the affairs of the people are organized, while it is assumed that the essence of Islam focuses on the existence of a free, believing and united nation. Hence the focus of the Qur'an on the existence of such a nation, while we note that the Qur'an regarding the system of government is limited to clarifying its characteristics without talking about the form of this ruling. The new rules that Islam came to regulate behavior and transactions were a prelude to a political organization that stabilized over time, and was affected by the surrounding environment, especially the Persians and the Romans, so it moved from spiritual rule during the era of the Rightly Guided Caliphs to political rule in the time of the Umayyads and the Abbasids. Islam did not specify a fixed form of government, be it caliphate, king, presidency, or anything else, but it was concerned with adopting a set of organizational principles for required characteristics such as justice and equality. In the end, Islam from the point of view of the ruling system did not care about names, whether it was the caliph or the president, but we can say that it is concerned with the need for Muslims to agree on it, and this leads us to say that the ruler should be elected from the nation, this system is not much different from what Western democracy recognizes at the present time. 


\section{Recommendations}

1. Activating the codification of the provisions of Islamic jurisprudence and work to expand it.

2. The possibility of combining the two systems (Islamic and positive law) in application, provided that it does not violate the provisions of Islamic law.

3. Focusing on this issue in the fight against terrorism, with the aim of showing the contradiction between the terrorists' demands and the reality of their actions.

\section{Refrences}

Abdul Hadi, J. (2014). Legalizing Islamic jurisprudence [Conference session]. Ministry of Religious Affairs, Muscat, Oman. http://alwatan.com/details/12630

Ahmad, A. (2001). The role of Islamic law in the contemporary world order. J. Islamic L. \& Culture, 6 (1), 140- 148.

Al Bishri, T. (2012). Legalizing Islamic law in the people's Assembly. Goodreads. https://goodreads.com/book/

Al Faidi, A. (2015). The origin of the jurisprudential differences in the issue of codifying the provisions of Islamic law. Journal of Alexandria Thought House. 21(1), 33-43. https://malcat.uum.edu.my/iium.u530206

Ansary, A. F. (2008). Combating extremism: A brief overview of Saudi Arabia's approach. Middle East Policy, 15(2), 111.doi: 10.1111/j.1435-4957.2008. 00353.

Colin, K. (2019). "Beyond the Caliphate: The Future of Terrorism in 2020 After the Collapse of ISIS". Journal of The Future for Research and Advanced Studies, 17 (2), pp.3-5. Al

Zuhaili, W. (2014). Legalization efforts in Islamic jurisprudence. Journal of Resala foundation, 11(1), 26. https://elibrary.mediu.edu2218

Hamele, M., Poss, W. B., \& Sweney, J. (2014). Disaster preparedness, pediatric considerations in primary blast injury, chemical, and biological terrorism. World journal of critical care medicine, 3(1), 10-18.doi: 10.5492/wjccm.v3.i1.15

Hasan, N. (2007). Islamic militancy, sharia, and democratic consolidation in post-Suharto Indonesia. https://dr.ntu.edu.sg/handle/10356/79795

Hassan, I., Azmi, M. N., \& Abubakar, U. I. (2017). Framing Islam in news reporting: A Comparative content analysis. Asian Social Science, 13(10), 105-116. doi:10.5539/ass. v13n10p112

Hassan, M. H. B. (2006). Key considerations in counter ideological work against terrorist ideology. Studies in conflict \& Terrorism, 29(6), 524-529.doi: $10.1080 / 10576100600791058$

Piazza, J. A. (2009). Is Islamist terrorism more dangerous? An empirical study of group ideology, organization, and goal structure. Terrorism and Political Violence, 21(1), 58 73.doi: $10.3109 / 10673229.2010 .533005$

Ramakrishna, K. (2016). Towards a comprehensive approach to combating violent extremist ideology in the digital space: The counter-ideological response (CIR) model. In Combating Violent Extremism and Radicalization in the Digital Era (pp. 212-231). IGI Global.doi: 10.4018/978-1-5225-0156-5.ch013

Rana, M. A. (2008). Cunter-ideology: unanswered guestions and the case of Pakistan. Perspectives on Terrorism, 2(3), 2-6. https://www.jstor.org/stable/26298334

Ryan, M. W. (2018). Defeating ISIS and Al-Qaeda on the Ideological Battlefield: The Case for the Corporation Against Ideological Violence. Retrieved from: https://digital commons.usnwc.edu/ciwag-case-studies/16/ 
INTERNATIONAL JOURNAL OF ACADEMIC RESEARCH IN BUSINESS AND SOCIAL SCIENCES

Vol. 10, No. 11, 2020, E-ISSN: $2222-6990$ @ 2020 HRMARS

Schouten, R. (2010). Terrorism and the behavioral sciences. Harvard review of psychiatry, 18(6), 345-358.doi: 10.1080/09546550802544698 